\title{
Nutrient and light limitation of periphyton in the River Thames: Implications for catchment management
}

\author{
M.J. Bowes ${ }^{\text {a,* }}$, N.L. Ings ${ }^{\text {a,b }}$, S.J. McCall a , A. Warwick ${ }^{\text {a }}$, C. Barrett ${ }^{\text {a }}$, H.D. Wickham ${ }^{\text {a }}$, S.A. Harman ${ }^{\text {a }}$, \\ L.K. Armstrong a, P.M. Scarlett ${ }^{\text {a }}$, C. Roberts ${ }^{\text {a }}$, K. Lehmann ${ }^{\text {a }}$, A.C. Singer ${ }^{\text {a }}$ \\ a Centre for Ecology and Hydrology, Maclean Building, Crowmarsh Gifford, Wallingford, Oxfordshire, OX10 8BB, UK \\ b School of Biological and Chemical Sciences, Queen Mary, University of London, Mile End Road, London, E1 4NS, UK
}

\section{A R T I C L E I N F O}

\section{Article history:}

Received 19 April 2011

Received in revised form 1 September 2011

Accepted 7 September 2011

Available online 26 October 2011

\section{Keywords:}

Algae

Biofilm

Flume mesocosms

Eutrophication

CEH Thames Initiative

Seacourt Stream

\begin{abstract}
A B S T R A C T
Soluble reactive phosphorus (SRP) concentrations in the River Thames, south east England, have significantly decreased from an annual maximum of $2100 \mu \mathrm{g} \mathrm{I}^{-1}$ in 1997 to 344 in 2010, primarily due to the introduction of phosphorus $(\mathrm{P})$ removal at sewage treatment works within the catchment. However, despite this improvement in water quality, phytoplankton biomass in the River Thames has greatly increased in recent years, with peak chlorophyll concentrations increasing from $87 \mu \mathrm{g} \mathrm{l} \mathrm{l}^{-1}$ in the period 1997 to 2002 , to $328 \mu \mathrm{g} \mathrm{l}^{-1}$ in 2009 . A series of within-river flume mesocosm experiments were performed to determine the effect of changing nutrient concentrations and light levels on periphyton biomass accrual. Nutrient enrichment experiments showed that phosphorus, nitrogen and silicon were not limiting or co-limiting periphyton growth in the Thames at the time of the experiment (August-September 2010). Decreasing ambient SRP concentration from $225 \mu \mathrm{g} \mathrm{l^{-1 }}$ to $173 \mu \mathrm{g} \mathrm{l^{-1 }}$ had no effect on periphyton biomass accrual rate or diatom assemblage. Phosphorus limitation became apparent at $83 \mu \mathrm{g}$ SRP $1^{-1}$, at which point a $25 \%$ reduction in periphyton biomass was observed. Diatom assemblage significantly changed when the SRP concentration was reduced to $30 \mu \mathrm{g} \mathrm{l}^{-1}$. Such stringent phosphorus targets are costly and difficult to achieve for the River Thames, due to the high population density and intensive agriculture within the Thames basin. Reducing light levels by shading reduced the periphyton accrual rate by $50 \%$. Providing shading along the River Thames by planting riparian tree cover could be an effective measure to reduce the risk of excessive algal growth. If the ecology of the Thames is to reach the WFD's "good ecological status", then both SRP concentration reductions (probably to below $100 \mu \mathrm{g} \mathrm{l}^{-1}$ ) and increased shading will be required.
\end{abstract}

Crown Copyright @ 2011 Published by Elsevier B.V. All rights reserved.

\section{Introduction}

The reduction of phosphorus (P) loading to UK rivers is seen as the key measure in reducing excessive algal growth and other problems associated with freshwater eutrophication, and thereby vital in delivering the "good ecological status" that is demanded by the European Union's Water Framework Directive (WFD). Many UK rivers have seen significant reductions in P concentration, due primarily to the introduction of phosphate removal at sewage treatment works (STW) (Bowes et al., 2009; Bowes et al., 2010b; Foy, 2007; Jarvie et al., 2002b; Neal et al., 2010a). These reduced P loadings have delivered the intended improvements in ecology in some rivers (Bowes et al., 2011; Kelly et al., 2009), but many others have seen no change in either algal biomass or community structure (Kelly and Wilson, 2004;

\footnotetext{
* Corresponding author. Tel.: + 4401491838800.

E-mail address: mibo@ceh.ac.uk (M.J. Bowes).
}

Neal et al., 2010b), because the current P concentrations are still in excess, and therefore do not limit algal growth rate.

If algal growth in a particular nutrient-enriched river is to be controlled by reducing phosphorus concentration, it is vital that catchment managers and policy makers know the threshold phosphorus concentration at which the algae become P-limited. If nutrient mitigation results in a river phosphorus concentration below this threshold value (termed the Phosphorus Limiting Concentration), algal growth will begin to decline, resulting in a potential shift in river ecology towards good ecological status (Hilton et al., 2006). If the phosphorus concentration remains above the P Limiting Concentration following mitigation, algal growth rate will continue unabated, and there is unlikely to be a change in river ecology. Previous studies have shown that Phosphorus Limiting Concentrations vary greatly from river to river, ranging from less than $20 \mu \mathrm{g} \mathrm{l}^{-1}$ SRP (Bothwell, 1985; Chambers et al., 2006; Popova et al., 2006; Welch et al., 1989) to ca. $100 \mu \mathrm{g} \mathrm{l} \mathrm{l}^{-1}$ or greater (Bowes et al., 2007; Matlock et al., 1999). Although the reduction of phosphorus loadings to rivers is seen as the main tool being used by government environmental and conservation agencies to control algal growth and improve ecological status in UK rivers, there are other 
parameters that can also affect algal accrual rate; in particular flowvelocity and light. Increasing river flow velocity can increase the scouring of epilithic and epiphytic biofilms from their substrates (Horner et al., 1990), thereby reducing shading of macrophyte leaves and 'cleaning' gravel substrates, thus increasing their utility as invertebrate habitat and potential fish spawning grounds. Increased flow velocity will also decrease residence times for phytoplankton (autotrophic organisms that are suspended within a water body), meaning that they have less time in the river to proliferate (Hilton et al., 2006). Light intensity within the river channel also affects the rate of algal growth (Hill and Fanta, 2008; Mosisch et al., 2001). Recent modelling studies on the River Swale, northern England, have suggested that reducing light levels in river headwaters by increasing riparian shading could be a more effective means of reducing phytoplankton growth than reducing phosphorus concentration (Hutchins et al., 2010).

In this paper, phosphorus and suspended chlorophyll- $a$ concentration data for the River Thames from 1997 to 2010 are presented. These data were used to test the hypothesis that the improvements in water quality observed in other studies (Kinniburgh and Barnett, 2010; Neal et al., 2010a) have reduced phytoplankton concentration in the Thames. This paper then aimed to identify the Phosphorus Limiting Concentration of periphyton (attached biofilm) for the River Thames near Oxford, using within-river flume mesocosms. The flume mesocosms were also used to identify if the other major plant nutrients, nitrogen and silicon, were limiting or co-limiting biofilm development, and how increases in $\mathrm{P}, \mathrm{N}$ and $\mathrm{Si}$ affect periphyton community structure. Finally, this paper aims to determine if decreased light intensity (equivalent to shading from riparian tree cover) will decrease periphyton accrual rates.

\subsection{Catchment description}

The River Thames is the largest river that is wholly in England, with a total length of $354 \mathrm{~km}$ and a catchment area (to the tidal limit at Teddington in south west London) of $9948 \mathrm{~km}^{2}$ (Marsh and Hannaford, 2008). The river rises at Thames Head in Gloucestershire, and flows in an easterly direction into the North Sea, east of London (Fig. 1). The Thames basin not only contains the UK's capital, London, but also many other major urban centres, including Swindon, Oxford, Slough, Maidenhead and Reading. The many STW associated with this high human population density (ca. 960 people $\mathrm{km}^{-2}$ (Merrett, 2007)) have a major impact on the water quality of the River Thames, with an estimated $50 \%$ of the soluble reactive phosphorus (SRP) load derived from STW effluent between 1997 and 1999 for the relatively rural middle reaches of the Thames at Wallingford (Bowes et al., 2010b). Tertiary treatment has been installed at the 36 largest STW (serving approximately 2.7 million people) upstream of the tidal limit since 2003, resulting in an average $85 \%$ reduction in phosphorus load from each sewage works (Kinniburgh and Barnett, 2010). This has resulted in significant reductions in SRP concentration in the River Thames and its tributaries during the 2000s (Kinniburgh and Barnett, 2010; Neal et al., 2010a). Over the coming decade, the population within the Thames basin is likely to increase further, with the planned building of an extra 375000 homes within the basin by

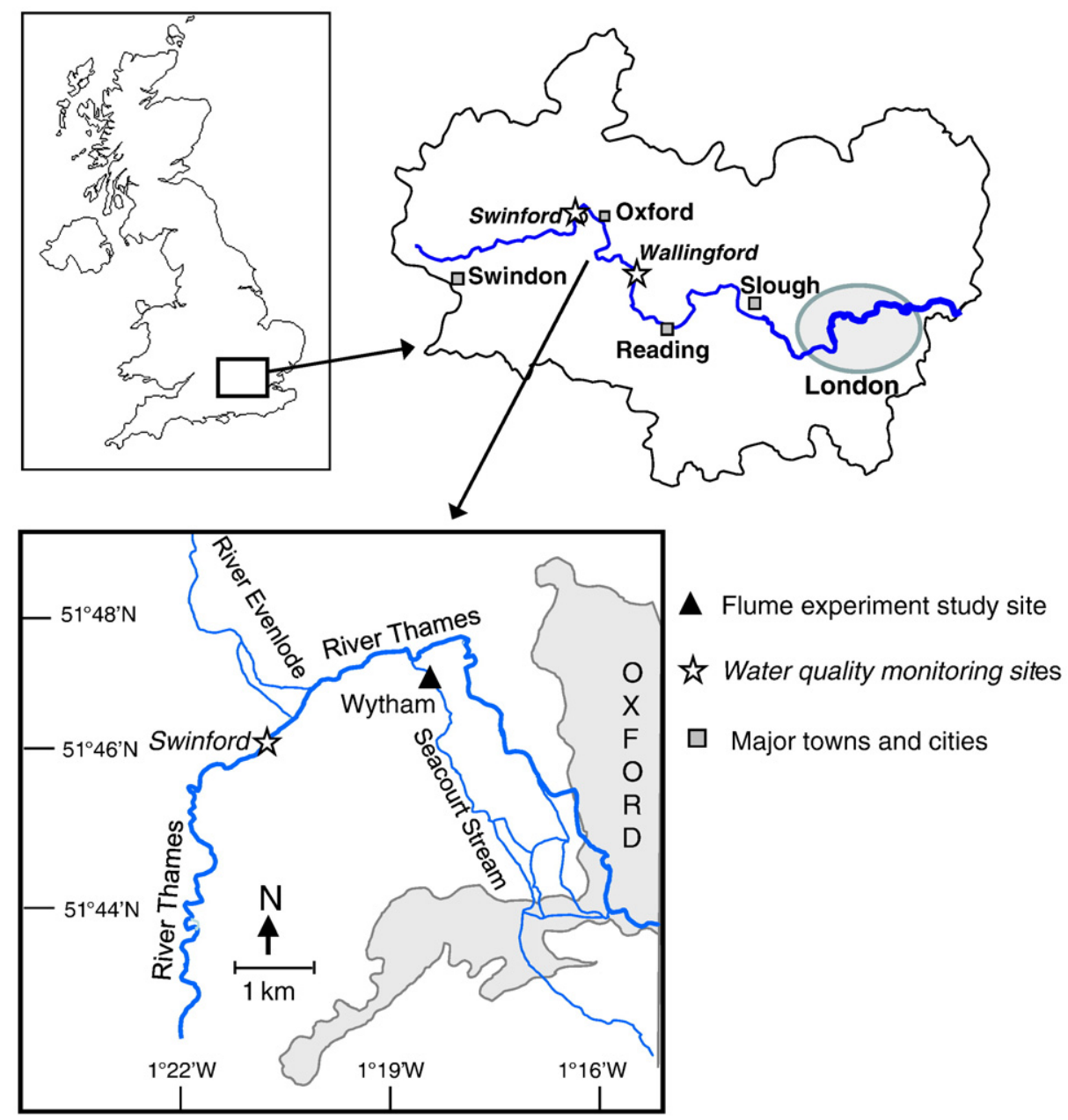

Fig. 1. Map of Thames basin, showing location of flume experiments (Seacourt Stream, Wytham) and water quality monitoring sites. 
2016 (Environment_Agency, 2009). This will greatly increase pressures on drinking water supplies, wastewater treatment, water quality and river ecology (Evans et al., 2003; Neal and Jarvie, 2005). These pressures are likely to be exacerbated by projected climate change scenarios that predict declining river flows and increasing water temperatures (Johnson et al., 2009).

Despite the high population density, much of the River Thames basin upstream of London is relatively rural (Environment_Agency, 2009 ), with ca. $45 \%$ of land area being classified as arable, $11 \%$ woodland and 34\% grassland (Fuller et al., 2002). Only ca. 6\% of the catchment land cover was urban or semi-urban development. Agriculture is relatively intensive, and the resulting diffuse phosphorus, nitrogen and sediment losses will impact on water quality within the basin.

\subsection{Study sites}

The flume mesocosms experiments took place on the Seacourt Stream at Wytham, which is a small distributary/mill stream that is fed directly by the River Thames, just west of the city of Oxford (Fig. 1). The Seacourt Stream was chosen to carry out nutrient limitation and shading experiments, rather than the River Thames itself, as the Thames is too deep for fieldworkers to safely operate the flumes. The Thames is also extensively used by leisure boats, and the large flume mesocosms used in this study would pose a hazard to this boat traffic. Twelve flumes (4 sets of 3 flumes) were installed ca. 50-80 $\mathrm{m}$ from the River Thames, along a relatively straight, uniform flowing section of river with a negligible amount of riparian shading. Maximum average river depth and width were ca. $1 \mathrm{~m}$ and 5-6 $\mathrm{m}$ respectively. Land use at the site was grassland, with sheep and cattle grazing. Simultaneous water sampling and analysis of the Seacourt Stream and Thames (just upstream of the confluence) showed that there was no observable change in nutrient concentrations taking place within the Seacourt Stream itself, due to interactions with bed sediments or biota, and so the flume experiments were carried out on unaltered River Thames water.

The water quality and chlorophyll- $a$ concentration of the River Thames at Wallingford (Fig. 1) has been monitored at weekly interval from 1997 to 2002, 2006 to 2007 (Neal et al., 2010a), and from February 2009 until present, as part of the Centre for Ecology and Hydrology's Thames Initiative research platform. Water quality was also monitored at weekly intervals since February 2009 for the River Thames at Swinford (ca. $2 \mathrm{~km}$ upstream of the Seacourt Stream study site) (Fig. 1).

\section{Methodology}

\subsection{Water quality analysis}

Samples of river water were taken manually at weekly interval from the main flow of the River Thames at Wallingford (1997 to 2010) and Swinford (2009 to 2010). Subsamples were filtered immediately in the field $(0.45 \mu \mathrm{m}$ cellulose nitrate membrane filter, WCN grade; Whatman, Maidstone, UK), and analysed for nutrient concentration. Soluble reactive phosphorus was determined using the phosphomolybdenum blue colorimetry method of Murphy and Riley (1962), as modified by Neal et al. (2000). Samples were analysed within $24 \mathrm{~h}$, to minimise errors associated with sample instability (House and Warwick, 1998; Jarvie et al., 2002a). SRP is considered equivalent to bioavailable phosphorus (House, 2003). Dissolved reactive silicon concentration was determined by reaction with acid ammonium molybdate, to form yellow molybdosilicic acids. These were then reduced using an acidified tin (II) chloride solution to form intensely coloured silicomolybdenum blues, which were quantified spectrophotometrically using a Descrete Analyser (Auto Analyser 2; Seal Analytical, Fareham, UK) (Mullin and Riley, 1955). Nitrate-N concentration was analysed by ion chromatography (Dionex DX500). Chlorophyll- $a$ concentration was determined by filtering a known volume of river water (ca. $500 \mathrm{ml}$ ) through a filter paper (GF/C; Whatman, Maidstone, UK) and extracting the pigment using a solvent. The quantity of chlorophyll$a$ was then determined spectrophotometrically. The River Thames samples from 1997 to 2007 were extracted using ethanol (Neal et al., 2006), and from 2009 onwards, $90 \%$ acetone was used for the pigment extraction (Marker et al., 1980). Parallel testing of river samples by the two solvent extraction techniques showed there was no observable difference between the two chlorophyll methods.

\subsection{Flume mesocosm experiments}

Within-stream through-flow flumes were used in this study to produce a range of nutrient concentrations, flows and light levels, simultaneously, at a single point in the river (Bowes et al., 2010a) (Fig. 2), allowing the effect of these perturbations on biofilm accrual rate within each flume to be investigated. The flumes were fabricated from polyvinyl chloride (PVC) sheeting. Each flume was $5 \mathrm{~m}$ long and $0.3 \mathrm{~m}$ wide, with gates at the upstream end, to control the flow rate of river water entering them. The flumes were grouped in sets of three, and secured within aluminium frames to minimise flexing. Floats were attached along the sides of each set of three flumes, to maintain them at a constant water depth of $4 \mathrm{~cm}$, irrespective of the changing water depth in the river. Because the flumes are floating at a constant depth within the water column, approximately $0.5 \mathrm{~m}$ above the bed sediment, they were not colonised by invertebrates, which would have a major effect on the amount of biofilm accrual that is observed during the experiments, due to grazing. The flumes were secured in place in the river by sliding them over metal poles that were driven into the river bed. Each flume had a $3 \mathrm{~cm}$ deep and $15 \mathrm{~cm}$ long sump, two thirds of the way down the flume (Fig. 2), to collect chemical precipitate (from phosphorus reduction treatments used during the Experiment 1 (described below)) and river debris that entered the flume, preventing it from entering the lower section of the flume. Unglazed ceramic tiles $(7 \mathrm{~cm} \times 7 \mathrm{~cm})$ were placed in this downstream section of each flume, to act as substrates for periphyton growth. Periphyton is a complex community of algae, cyanobacteria, heterotrophic microbes and associated detritus that produces a biofilm on within-river surfaces. The rate of periphyton colonisation on new surfaces such as macrophyte leaves has been identified as the key process in ecological community degradation, associated with stream eutrophication (Hilton et al., 2006).

\subsubsection{Effect of phosphorus concentration changes on periphyton (Experiment 1)}

A phosphorus manipulation experiment was begun on the 18th August 2010. Six flumes were deployed in the Seacourt Stream at Wytham, in a river stretch with no shading from riparian vegetation and relatively uniform flow. The flumes were deployed in clusters of three, with a control and two nutrient treatments within each cluster. The flow-control gates at the upstream end of each flume (Fig. 2) were adjusted until a water velocity of $0.10 \mathrm{~m} \mathrm{~s}^{-1}$ (measured using a Valeport model 801 electromagnetic flow meter (Valeport Ltd.,

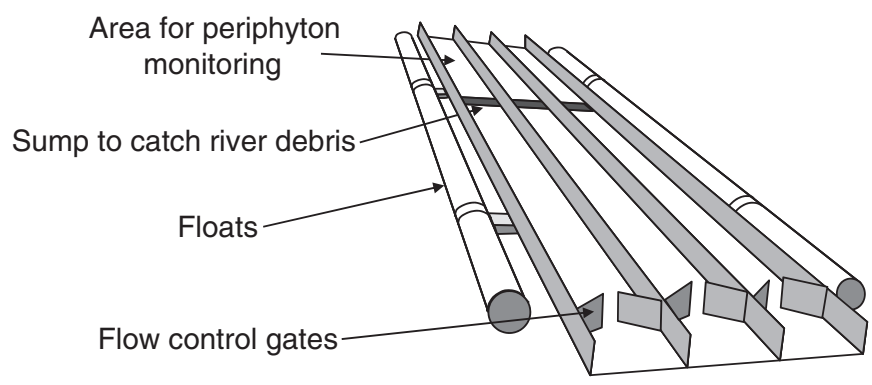

Fig. 2. Diagram of flume mesocosms. 
Totnes, UK)) was produced in the middle section of each flume. One flume in each cluster received no chemical additions, and therefore had unmodified Thames river water running through it. These acted as experimental controls. Treatments were randomly assigned to the four remaining flumes, to simultaneously produce a range of phosphorus concentrations, spanning the ambient river concentration at the time of the experiment (Table 1). One of the flumes received a continuous addition of concentrated potassium dihydrogen orthophosphate solution into the upper section of the flume, to produce a $c a$. $60 \%$ increase in the average ambient phosphorus concentration (which was $205 \mu \mathrm{g} \mathrm{l}^{-1}$ at the start of the experiment). The three remaining flumes had the SRP concentration in the incoming river water reduced, using the P-stripping methodology developed by Bowes et al. (2007). These flumes received continuous additions of a concentrated iron (II) sulphate solution. This added iron solution reacted with the soluble, bioavailable phosphate in the incoming river water, forming a non-bioavailable precipitate of $\mathrm{Fe}_{3}\left(\mathrm{PO}_{4}\right)_{2}$ (Reynolds and Davies, 2001; Suschika et al., 2001), thereby reducing the SRP concentration within the flume. The iron addition rates were adjusted until the SRP concentrations in the incoming river water (measured in the lower part of the flumes, where the tile substrates were to be positioned) were reduced to approximately 75,30 and $20 \%$ of the current ambient SRP concentration. These phosphorus and iron additions were delivered to the upstream end of the flumes (to allow the chemical treatments to fully mix with the incoming river water and to allow time for the iron-phosphorus precipitation reaction to occur before the water reached the downstream periphyton-monitoring section of the flumes) from stock solutions on the river bank via pipes, using a multi-channel peristaltic pump.

When the required SRP concentrations were achieved, unglazed ceramic tiles were placed in the lower section of each flume, to provide substrates for periphyton growth. The SRP concentrations were monitored two to three times per day. Water samples $(60 \mathrm{ml})$ were taken from the lower section of the flumes (where the ceramic tiles were positioned), immediately filtered through a $0.45 \mu \mathrm{m}$ cellulose nitrate membrane filter (WCN grade; Whatman, Maidstone, UK) and analysed for SRP concentration (within 30 min of sampling) using a Micromac 1000 field autosampler/analyser (Systea Analytical Technologies, Anagni, Italy). Parallel investigations during this experiment and in previous flume studies (Bowes et al., 2010a; Bowes et al., 2007) confirmed that filtering the iron-dosed river water stopped the phosphorus stripping reaction, thereby allowing the true SRP concentration overlying the periphyton to be quantified. A randomly allocated tile was removed from each flume at two day intervals, to determine periphyton biomass by chlorophyll- $a$ analysis.

After nine days (27th August, 2009), most of the tiles had developed a thick periphyton biofilm layer, and sloughing appeared to be imminent. The six remaining tiles in each flume and associated periphyton were carefully removed, and returned to the laboratory for chlorophyll- $a$ analysis and algal community identification/quantification. These replicate tiles were used to provide information on within-flume variability in periphyton accrual rates and algal community structure.

\subsubsection{Effect of increasing nutrient concentrations on periphyton (Experiment 2)}

On the 18th August 2010, approximately $30 \mathrm{~m}$ upstream of the phosphorus manipulation experiment described above, a second flume experiment was undertaken, to investigate if periphyton in the River Thames was phosphorus, nitrogen or silicon limited/co-limited. As with Experiment 1, this study was conducted in two clusters of three flumes, one flume in each cluster randomly assigned to receive no chemical additions to the incoming river water, serving as an experimental control. The remaining four flumes had one or more of their $\mathrm{P}$, $\mathrm{N}$, and Si concentrations in the incoming river water increased, by the continuous addition of concentrated solutions of potassium dihydrogen orthophosphate $\left(\mathrm{KH}_{2} \mathrm{PO}_{4}\right)$, sodium nitrate $\left(\mathrm{NaNO}_{3}\right)$ and sodium silicate solution $\left(\mathrm{Na}_{2} \mathrm{O}_{7} \mathrm{Si}_{3}\right)$ to the upstream end of the flume (Table 1$)$. The treatments in these four flumes were: $\mathrm{N}, \mathrm{P}, \mathrm{P}+\mathrm{N}$, and $\mathrm{P}+\mathrm{N}+\mathrm{Si}$. The nutrient enrichment treatments allocated to each flume are given in Table 1 . The $\mathrm{P}$ and $\mathrm{N}$ stock solutions were made by dissolving $\mathrm{KH}_{2} \mathrm{PO}_{4}$ and $\mathrm{NaNO}_{3}$ in deionised water. The silicon stock solution was produced by adding sodium silicate solution (dissolved in concentrated $\mathrm{NaOH}$ ) to the alkaline river water from the study site, to minimise silicon precipitation within the stock solution. The openings in the gates at the upstream end of each flume were adjusted to give a standard flow velocity of $0.08 \mathrm{~m} \mathrm{~s}^{-1}$ in the middle of each flume. Unglazed ceramic tiles were then placed in the lower part of each flume to act as periphyton growth substrates. Water samples were taken from the lower section of each flume and immediately filtered through a $0.45 \mu \mathrm{m}$ cellulose nitrate membrane filter (WCN grade; Whatman, Maidstone, UK). SRP

Table 1

Nutrient and light treatments applied during flume experiments.

\begin{tabular}{|c|c|c|c|c|}
\hline Experiment number & Dates (Duration) & Flume number & Treatment & Flow velocity $\left(\mathrm{m} \mathrm{s}^{-1}\right)$ \\
\hline \multirow[t]{6}{*}{ Experiment 1} & 18th to 27th August 2010 & 1 & Control & 0.10 \\
\hline & (9 days) & 2 & $P$ addition (60\% increase in initial $P$ concentration) & 0.10 \\
\hline & & 3 & Iron addition ( $30 \%$ decrease in initial $\mathrm{P}$ concentration) & 0.10 \\
\hline & & 4 & Iron addition (70\% decrease in initial $\mathrm{P}$ concentration) & 0.10 \\
\hline & & 5 & Iron addition ( $20 \%$ decrease in $\mathrm{P}$ concentration) & 0.10 \\
\hline & & 6 & Control & 0.10 \\
\hline \multirow[t]{6}{*}{ Experiment 2} & 18th to 27th August 2010 & 1 & $\mathrm{~N}$ addition & 0.08 \\
\hline & (9 days) & 2 & $\mathrm{P}, \mathrm{N}$ and $\mathrm{Si}$ addition & 0.08 \\
\hline & & 3 & Control & 0.08 \\
\hline & & 4 & $\mathrm{P}$ and $\mathrm{N}$ addition & 0.08 \\
\hline & & 5 & Control & 0.08 \\
\hline & & 6 & $\mathrm{P}$ addition & 0.08 \\
\hline \multirow[t]{12}{*}{ Experiment 3} & 7th to 17 th September 2010 & 1 & No shading & 0.10 \\
\hline & (10 days) & 2 & Full shading & 0.10 \\
\hline & & 3 & Intermediate shading & 0.10 \\
\hline & & 4 & No shading & 0.10 \\
\hline & & 5 & Intermediate shading & 0.10 \\
\hline & & 6 & Full shading & 0.10 \\
\hline & & 7 & Full shading & 0.15 \\
\hline & & 8 & Intermediate shading & 0.15 \\
\hline & & 9 & No shading & 0.15 \\
\hline & & 10 & Intermediate shading & 0.15 \\
\hline & & 11 & No shading & 0.15 \\
\hline & & 12 & Full shading & 0.15 \\
\hline
\end{tabular}


analysis was carried out daily on site (at the University of Oxford's Wytham Field Station Laboratories) using a Micromac 1000 field nutrient analyser (Systea Analytical Technologies, Anagni, Italy). Silicon and nitrate samples were taken every two to three days, returned to the Centre for Ecology and Hydrology (CEH) Wallingford laboratories and analysed within $24 \mathrm{~h}$.

A randomly selected tile was removed at 2 day intervals throughout the experiment, for chlorophyll- $a$ analysis. The experiment was terminated after 9 days, as some of the tiles were showing signs of having lost some periphyton biomass due to sloughing. The remaining tiles (six per flume) were removed and analysed for chlorophyll-a concentration and algal composition analysis.

\subsubsection{Effect of light intensity on periphyton (Experiment 3)}

Light intensities were measured in direct sunlight, and a range of dappled tree shade and full tree shade, using a $1 \mathrm{~m}$ long light probe (SunScan, model SS1), around midday on a sunny day in September 2010. Dappled and full tree shade reduced the light intensity by 46 and $71 \%$ respectively. Sheets of plastic mesh (greenhouse shading material) were then layered above the light meter, until shading levels equivalent to that of partial and full tree shading were obtained. These numbers of mesh layers were then placed over the downstream sections of the flumes, to recreate the light intensities equivalent to these different levels of tree shading. Previous studies have successfully used similar approaches to investigate light limitation of periphyton (Hill et al., 2009). Each set of three flumes contained an unshaded, intermediate shaded (equivalent to dappled tree shade) and fully shaded (equivalent to full tree canopy cover) flume. The positions of these shading treatments within each set of three flumes were allocated randomly (Table 1 ).

On 7th September, 2010, twelve flumes (four clusters of three flumes) were deployed at two points along a $30 \mathrm{~m}$ stretch of the Seacourt Stream, as described in Experiment 2. This third experiment aimed to examine the impact of light shading and flow velocity on periphyton biomass accrual and algal composition. Six of the flumes (two clusters of three) had the flow velocity of the incoming water set to $0.10 \mathrm{~m} \mathrm{~s}^{-1}$ (same as in Experiment 1), and the remaining six (30 m downstream of the first six flumes) had a higher velocity of $0.15 \mathrm{~m} \mathrm{~s}^{-1}$, which was the highest consistent flow that could be achieved by opening up the flow control gates in each flume. Fourteen unglazed ceramic tiles were placed in the lower section of each flume, underneath the shading material. Combined light/temperature loggers (HOBO pendent logger; Onset Computer Corporation, Massachusetts, USA) were placed alongside the tiles, to monitor levels of shading, and to determine if this shading reduced the water temperature within the flumes. The loggers were cleaned at two day intervals, to remove the colonising periphyton that was covering the light sensor, as this would cause errors in light intensity readings. Only light intensity readings taken after sensor cleaning were used to infer the effect of shading in each flume. Two tiles were removed from each flume at 2 day intervals, to determine chlorophyll- $a$ concentration and algal community composition. The experiment was ended on the 17th September, 2010 (after ten days), as sloughing of periphyton from the tiles appeared to be imminent. The remaining six tiles in each flume were removed for subsequent chlorophyll- $a$ and algal composition analysis.

\subsection{Periphyton biomass analyses}

The periphyton biomass that had accrued on each tile was estimated by chlorophyll- $a$ analysis. The entire periphyton biofilm was washed and scraped from each tile, using $300 \mathrm{ml}$ of deionised water. The resulting suspension was homogenised by vigorous stirring, and a $40 \mathrm{ml}$ sub-sample was taken and filtered through a GF/C grade filter paper (Whatman Ltd., Maidstone, UK). The filtered sub-samples were then extracted overnight at $4{ }^{\circ} \mathrm{C}$ in $90 \%$ acetone and the quantity of chlorophyll- $a$ in each sub-sample was quantified spectrophotometrically
(Marker et al., 1980). The total quantity of chlorophyll- $a$ on each tile was then back-calculated.

The total mass of periphyton and sediment covering the tile substrates was also quantified, by filtering another $40 \mathrm{ml}$ sub-sample of the $300 \mathrm{ml}$ homogenised suspensions (described above) through ashed, preweighed GF/C filter papers. The filter papers were then dried overnight at $60{ }^{\circ} \mathrm{C}$ before being cooled to room temperature in a desiccator and reweighed. The dry weight within each sub-sample was then used to calculate the dry mass on each tile $\left(\mathrm{g} \mathrm{cm}^{-2}\right)$. Following this, filter papers were ashed at $500{ }^{\circ} \mathrm{C}$ for $2 \mathrm{~h}$ in a muffle furnace (model AAF 1100 ; Carbolite Ltd., Hope, UK). After cooling overnight at $60^{\circ} \mathrm{C}$, filter papers were reweighed and the Ash Free Dry Mass (AFDM) on each tile back-calculated (which is equivalent to the organic content of the biofilm). Autotrophic Index was calculated by dividing the AFDM by the chlorophyll-a concentration (APHA, 1995). This gives an indication of the numbers of autotrophs in the biofilm, relative to heterotrophs and detritus.

For Experiment 3 (where replicate treatments were employed), a one-way analysis of variance (ANOVA) was used to test whether the different shading treatments in each flume had a significant effect on chlorophyll- $a$ concentrations. Post-hoc Tukey's multi comparison test followed significant ANOVA ( $p<0.05)$, to differentiate between mean chlorophyll- $a$ concentrations. If the chlorophyll concentration data were not normally distributed or the variances were unequal (tested using Levene's test), the data were log-transformed prior to analysis. Differences in periphyton biomass under different flow conditions in Experiment 3 were analysed using a two sample $t$-test.

\subsection{Diatom community analysis}

Diatom communities were investigated on three tiles per flume, sampled at the end of each experiment. The biofilm was scrubbed off each individual tile using a toothbrush and rinsed into a clean tray using deionised water. Samples were transferred to $50 \mathrm{ml}$ plastic tubes, kept cold and dark in the field and then frozen immediately on return to the laboratory. Defrosted samples were thoroughly mixed, before $c a .10 \mathrm{ml}$ of sample was placed in a beaker and cleaned using the 'hot peroxide method' (Kelly et al., 2001). Hydrogen peroxide solution (30\%) was added to each sample and these were then gently heated on a hotplate until the samples had turned clear. A few drops of $10 \%$ hydrochloric acid were added to remove carbonates, before samples were rinsed three times in deionised water. Samples were mounted onto slides using Naphrax (refractive index of 1.73, Brunel Microscopes Ltd, Chippenham, UK).

Frustules were identified according to the methods described in Kelly et al. (2001), using the keys of Krammer and Lange-Bertalot (2004a, b, 2007a,b) and Kelly et al. (2005). On each slide counting ceased once 300 frustules belonging to non-planktonic taxa had been identified. For Experiment 1, diatoms from all flumes were identified. In Experiment 2, diatoms from the $\mathrm{N}$ addition, N,P,Si addition and one control flume were identified (flumes 1 to 3; Table 1) and in Experiment 3, diatoms from flumes 4 to 12 were identified, to give three replicates of each level of shading (Table 1 ).

To investigate the effect of nutrient concentration on diatom community composition, the trophic diatom index (TDI) was calculated for each sample in Experiments 1 and 2 using the nutrient sensitivity and indicator values and the formula given in Kelly et al. (2001). Possible outcomes can range from 0 to 100 , with a 100 indicating extremely high nutrient concentrations. In addition, the percentage of the diatom community composed of motile species was calculated.

To characterise any differences in community composition between treatments, multivariate analyses were performed using CANOCO version 4.5 (Ter Braak, 1988-2003). Exploratory detrended correspondence analyses (DCA) indicated that gradient lengths were short (less than 2) and this, together with an inspection of species responses, suggested that linear methods would be most appropriate (Leps and Smilauer, 
2002). Redundancy analysis (RDA) was used to examine relationships between species and environmental data (SRP concentrations and levels of shading, input as nominal variables for Experiments 1 and 3 respectively and for Experiment 2 concentrations of SRP, N-nitrate and dissolved reactive silicon input as continuous variables) and Monte Carlo permutation tests were used to test the significance of the environmental variables. Principal components analysis (PCA) was used to show the variation in diatom community structure across the treatments. Changes in species diversity were also quantified using the Shannon diversity index.

\section{Results and discussion}

\subsection{Changes in River Thames water quality}

Phosphorus concentrations have decreased significantly in the River Thames at Wallingford since the late 1990s (Fig. 3). The maximum SRP concentrations observed in 1997 and 1998 were 2100 and $1788 \mu \mathrm{g} l^{-1}$ respectively, with mean annual concentrations of 1320 and $789 \mu \mathrm{g}^{-1}$. The annual maximum and mean SRP concentrations declined to ca. 800 and $420 \mu \mathrm{g} \mathrm{l} \mathrm{l}^{-1}$ in each of the following 3 years (1999 to 2001). Maximum and mean total phosphorus (TP) concentrations also declined from 2792 and $1461 \mathrm{gg} \mathrm{l}^{-1}$ in 1997 to 844 to $471 \mu \mathrm{g} \mathrm{l} \mathrm{I}^{-1}$ in 2001, respectively. Similar sudden declines in SRP concentration in 1999 have also been observed in Environment Agency (EA) water quality data for a monitoring site $2 \mathrm{~km}$ downstream of Oxford at Radley, and was attributed to the introduction of phosphorus removal at Swindon STW (with a population estimate of 199000 ) in the upper Thames catchment (Kinniburgh and Barnett, 2010). Further reductions in SRP concentration have been observed from 2002 to 2010 (Fig. 3), with maximum and mean concentrations in 2010 of 344 and $202 \mu \mathrm{g} \mathrm{l^{-1 }}$ respectively, and due principally to the introduction of P removal at 36 of the largest STWs in the catchment (Kinniburgh and Barnett, 2010). There has also been a $26 \%$ reduction in annual average $\mathrm{NO}_{3}-\mathrm{N}$ concentration during this monitoring period, decreasing from $8.9 \mathrm{mg} \mathrm{l}^{-1}$ in 1998 to $6.6 \mathrm{mg} \mathrm{l}^{-1}$ in 2010 .

However, this major improvement in water quality and reduction in trophic status observed in this study has not delivered the expected reduction in phytoplankton concentration. In fact, there has been an almost four-fold increase in chlorophyll- $a$ concentrations in recent years, with a maximum observed concentration of $87 \mu \mathrm{g} \mathrm{l} \mathrm{l}^{-1}$ between 1997 and 2002, increasing to $328 \mu \mathrm{g} \mathrm{l}^{-1}$ in 2009 (Fig. 2). This observation is at odds with the conclusions of Kinniburgh and Barnett (2010), who's chlorophyll concentration data from the years 1994 and 2006 implied that phytoplankton concentrations had begun to decline in the Thames, despite the orthophosphate concentrations still far exceeding the values they thought to be limiting to algal growth. The chlorophyll concentration in 2006 was actually the lowest observed within this study, with a maximum of less than $12 \mu \mathrm{g} \mathrm{l}{ }^{-1}$, despite the P concentration being similar to that in 2009. By combining the observations from these CEH and Environment Agency (EA) studies, and in particular the nutrient and chlorophyll- $a$ data from 2009 to 2010, it is now clear that declining SRP concentrations have not been reduced to algae-limiting levels, and other factors that control phytoplankton concentration (such as river ecology and food-web interactions, light, water temperature and flow) must be the cause of the low algal biomass observed in 2006 and the major algal bloom in 2009, rather than nutrient availability.

\subsection{Effect of phosphorus concentration changes on periphyton}

The SRP concentrations observed in each flume throughout the $\mathrm{P}$ manipulation experiment (Experiment 1) are shown in Fig. 4. The SRP concentration of the two control channels (equivalent to the ambient concentration in the Seacourt Stream) throughout the nine days of the experiment varied between 203 and $260 \mu \mathrm{g} \mathrm{l}^{-1}$, with an average concentration of $225 \mu \mathrm{g} \mathrm{l} \mathrm{l}^{-1}$. The flume receiving soluble phosphate additions varied from 297 to $480 \mu \mathrm{g} \mathrm{l}^{-1}$, with an average SRP concentration of $373 \mu \mathrm{g} \mathrm{l} \mathrm{l}^{-1}$, which was equivalent to a $66 \%$ increase in ambient SRP concentration over the course of the experiment. The three flumes receiving the iron sulphate additions had the SRP concentration of the incoming river water reduced by 24, 63 and $87 \%$, giving average SRP concentrations throughout the experiment of 171,83 and $30 \mu \mathrm{g} \mathrm{l}^{-1}$ respectively. The nitrate-N concentration during this experiment was $5.2 \mathrm{mg} \mathrm{l}^{-1}$, giving $\mathrm{N}: \mathrm{P}$ ratios ranging from $384: 1$ to $31: 1$ for the 30 and $373 \mu^{l^{-1}}$ respectively. The N:P ratio in the River Thames at the study site was 51 at the time of the experiment.

The rates of periphyton accrual in each flume (estimated by chlorophyll- $a$ concentration) through the course of the experiment are shown in Fig. 5, and the final average concentrations of chlorophyll- $a$ produced at the range of average SRP concentrations at the end of the experiment (day 9) are shown in Fig. 6. Fig. 5 shows that the amount of chlorophyll- $a$ on the tiles in one of the control flumes had started to decrease between days 8 and 9, corroborating the field observations during the experiment that periphyton biomass in some flumes had reached its maximum by day 9 , and that biofilm sloughing was beginning to take place. After nine days, the quantities of chlorophyll- $a$ produced by the P-addition flume, one of the control flumes, and the iron-addition

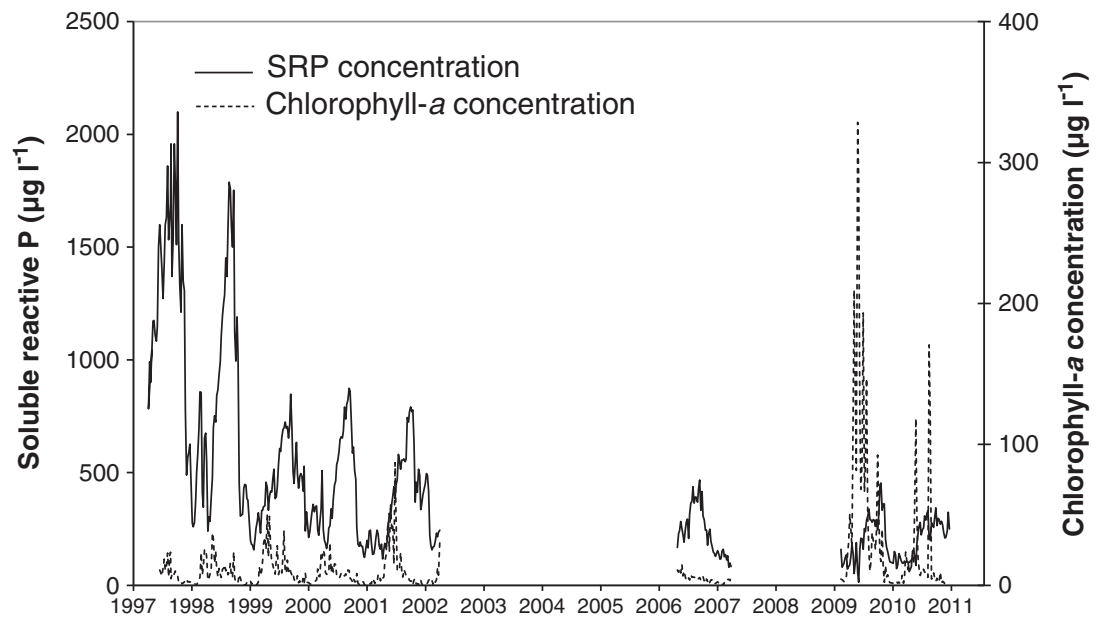

Fig. 3. Water quality monitoring data for the River Thames at Wallingford from 1997 to 2010 . 


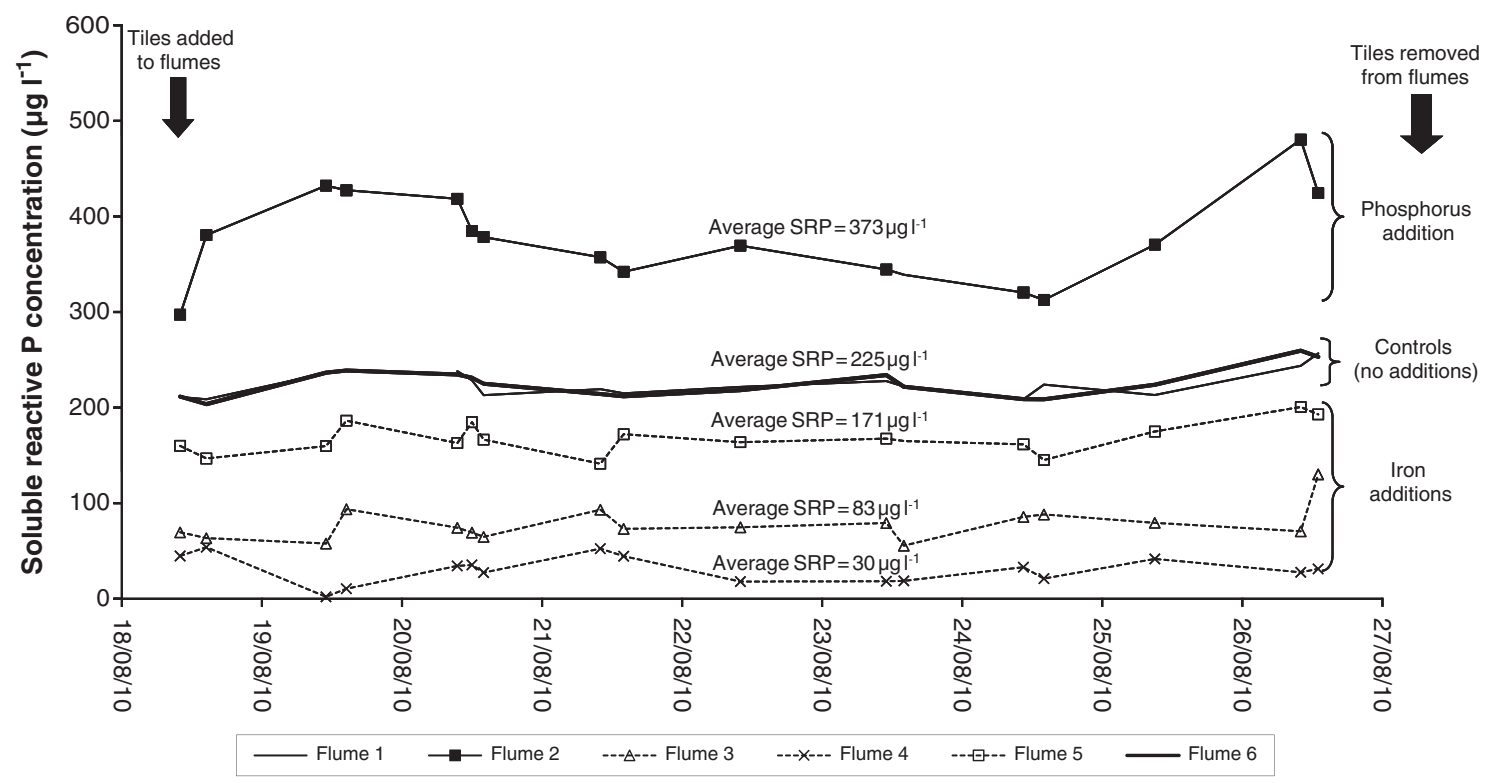

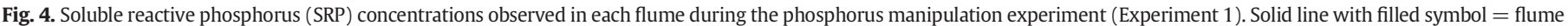

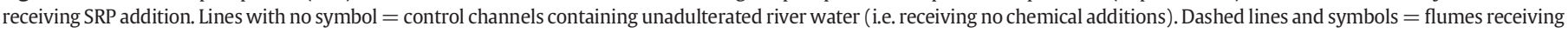
iron sulphate additions to convert SRP to non-bioavailable P forms.

flume with its average SRP concentration reduced to $171 \mu \mathrm{g} \mathrm{l}^{-1}$ were all similar, with chlorophyll- $a$ concentrations ranging from 12.6 to $13.2 \mu \mathrm{g} \mathrm{cm}^{-2}$ (Fig. 6). The dry mass of periphyton and sediment that had accumulated in these flumes varied between 21 and $23 \mathrm{mg} \mathrm{cm}^{-2}$, with an organic content (quantified by AFDM) of 15 to $16 \%$. The other control flume (with an SRP average of $225 \mathrm{gg} \mathrm{l}^{-1}$ ) had a lower quantity of periphyton biomass (chlorophyll-a concentration of $11 \mu \mathrm{g} \mathrm{cm}^{-2}$ ), due to the sloughing identified in Fig. 5. The two flumes that had their SRP concentrations reduced to 83 and $30 \mu \mathrm{g} \mathrm{l} l^{-1}$ had average chlorophyll- $a$ concentrations of 9.8 and $9.4 \mu \mathrm{g} \mathrm{cm}^{-2}$ respectively, equivalent to a 25 to $30 \%$ reduction when compared to the $c a .13 \mu \mathrm{g} \mathrm{cm}^{-2}$ of the other treatments, and a reduced dry mass of $\mathrm{ca} .18 \mathrm{mg} \mathrm{cm}^{-2}$. Autotrophic Index (AI) values varied from 190 to 253 , which indicate that the biofilm community is relatively well balanced between heterotrophic and autotrophic conditions (Ameziane et al., 2002). The highest AI value was from the flume with an average SRP concentration of $30 \mu \mathrm{g} \mathrm{l}{ }^{-1}$, indicating that the algal population has been suppressed at this low phosphorus concentration.

These results show that phosphorus is not limiting the rate of periphyton accrual in the River Thames at the time of this study. A 60\% increase in ambient SRP concentration from ca. 225 to $373 \mu \mathrm{g} \mathrm{l}^{-1}$ did not increase the rate of periphyton accrual, showing that phosphorus is in excess for periphyton growth. This explains why there has not been a reduction in phytoplankton biomass in the River Thames, despite a reduction in average annual SRP concentration from ca. $2000 \mu \mathrm{g} \mathrm{l}^{-1}$ in the late 1990s to $202 \mu \mathrm{g}^{-1}$ in 2010 . Reducing the SRP concentration to $171 \mu \mathrm{g} \mathrm{l^{-1 }}$ also had no effect on the biomass of periphyton produced. Phosphorus limitation was only observed in flumes with SRP concentrations of 83 and

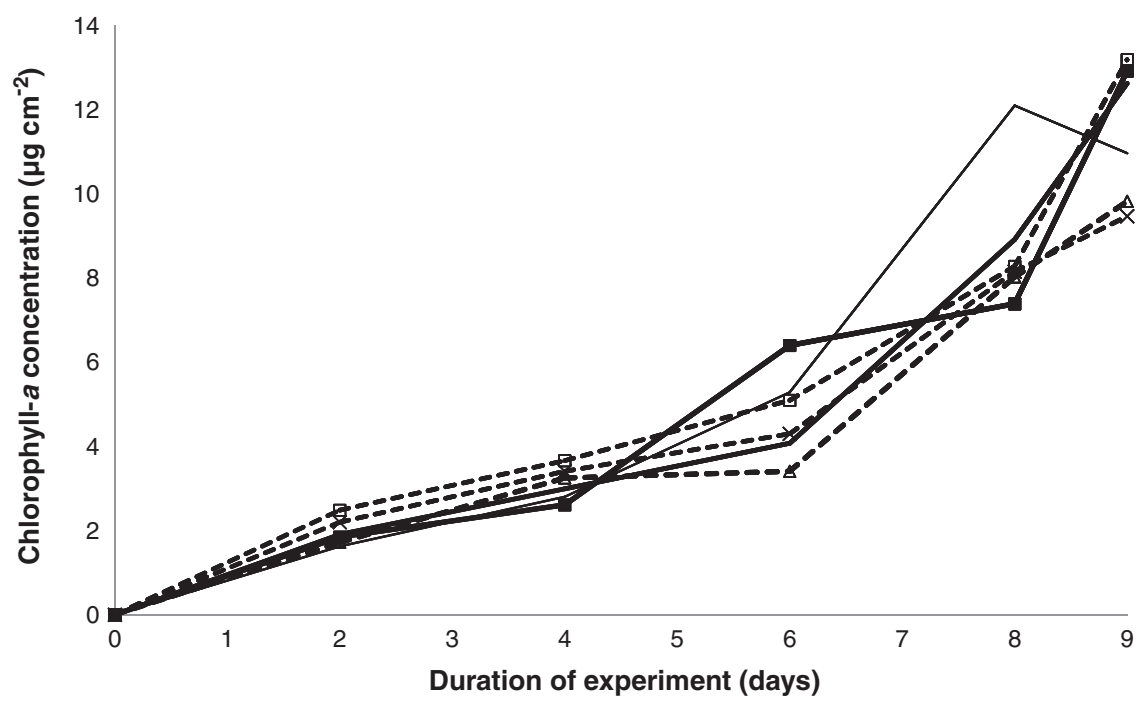

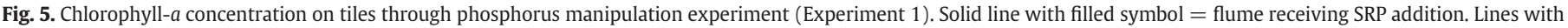

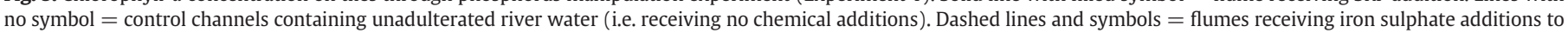
convert SRP to non-bioavailable P forms. The average SRP concentrations (in $\mu \mathrm{l}^{-1}$ ) observed in each flume are given in the graph legend. 


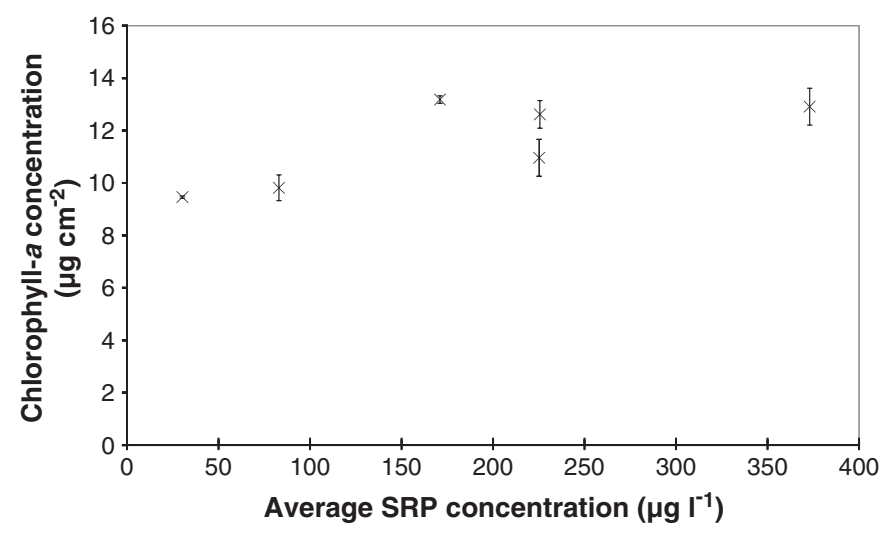

Fig. 6. Chlorophyll- $a$ concentrations on tile substrates at the end of Experiment 1 (9 days), resulting from a range of average SRP concentrations produced in each flume. Data points are mean values \pm 1 standard error, based on analysis of 3 tiles from each flume.

$30 \mu \mathrm{g} 1^{-1}$, but this only reduced the periphyton biomass by $c a .25 \%$. Therefore, the phosphorus limiting concentration in this part of the River Thames is between 83 and $171 \mu \mathrm{g} \mathrm{l^{-1 }}$. Similar periphyton limitation studies on the River Frome, Dorset and the River Kennet (a major tributary of the River Thames) identified phosphorus limiting concentrations of $c a .90$ and $60 \mu \mathrm{g} \mathrm{l} \mathrm{l}^{-1}$ SRP respectively (Bowes et al., 2010a; Bowes et al., 2007). As a reduction in SRP concentration to $83 \mu \mathrm{g} \mathrm{l^{-1 }}$ only resulted in a minor reduction in the periphyton biomass and accrual rate, it is likely that River Thames SRP concentration will probably need to be reduced to below $100 \mu \mathrm{g} \mathrm{l}^{-1}$ during the ecologically-active spring and summer period before a reduction in algal biomass and a potential improvement in ecological status would be observed.

In contrast to the chlorophyll- $a$ results, diatom community composition only significantly altered from that present at ambient SRP concentrations once SRP concentrations were reduced to $30 \mu \mathrm{g} \mathrm{I}^{-1}$, suggesting that the Phosphorus Limiting Concentration was between 30 and $83 \mu \mathrm{g} \mathrm{l}^{-1}$. This is illustrated in Fig. 7, with the three replicate samples from the $30 \mu \mathrm{g}$ SRP $1^{-1}$ flume markedly separated (largely along axis 1) from the other samples. Further support is provided by the RDA in which this treatment was the only one which significantly explained any variation (variation explained $32.4 \%, F=7.68$, $p=0.002$ ) in the diatom communities. This sudden shift in community composition at an SRP concentration of $30 \mu \mathrm{g} \mathrm{l}^{-1}$ is also apparent in terms of both diversity and the percentage of motile cells. This flume contained a greater diversity of diatoms and a reduced proportion of motile cells compared to all other flumes in this experiment (Table 3). The diatom community was characterised by an increase in the abundance of taxa in class 3 of the TDI, described as 'species favoured by intermediate concentrations of nutrients' (Kelly et al., 2001) and this was balanced by a slight reduction in taxa in sensitivity class 4 described as 'species favoured by high concentrations of nutrients'. Taxa in sensitivity class 3 that were more common under the lowest P concentrations included Suriella brebissonii, Navicula capitoradiata and Cocconeis placentula, whereas this flume contained a lower relative abundance of Nitzschia acicularis and $N$. capitellata, which were taxa from sensitivity class 4 (Fig. 7).

The TDI index values did not show any marked difference among treatments, which may suggest that this tool is relatively insensitive at SRP concentrations greater than $c a .50 \mu \mathrm{g} \mathrm{l}^{-1}$. However, it should be noted that the communities examined here were relatively young ( 9 days old), and TDI is usually applied to more mature and established communities. Despite this, the communities contained high algal standing crops and were sampled at a time at which sloughing appeared imminent, suggesting that the biofilm had reached its maximum biomass. The apparent lack of sensitivity of the TDI results to a magnitude change in SRP concentration may suggest that factors other than SRP concentration may control the diatom community composition at this site. These factors could include the deposition of algal cells from upstream, high propagule pressure, and the large amount of suspended sediment present within the river water (ca. $10 \mathrm{mg} \mathrm{l}^{-1}$ ). High rates of deposition of algal cells seems unlikely to account for the differences in chlorophyll concentrations and diatom community composition observed here as planktonic diatom species (mainly Cyclotella spp., Stephanodiscus spp. and Aulacoseira spp.), only accounted for $6.0 \pm 0.4 \%$ of all frustules identified across this study. These centric diatoms attained high abundances

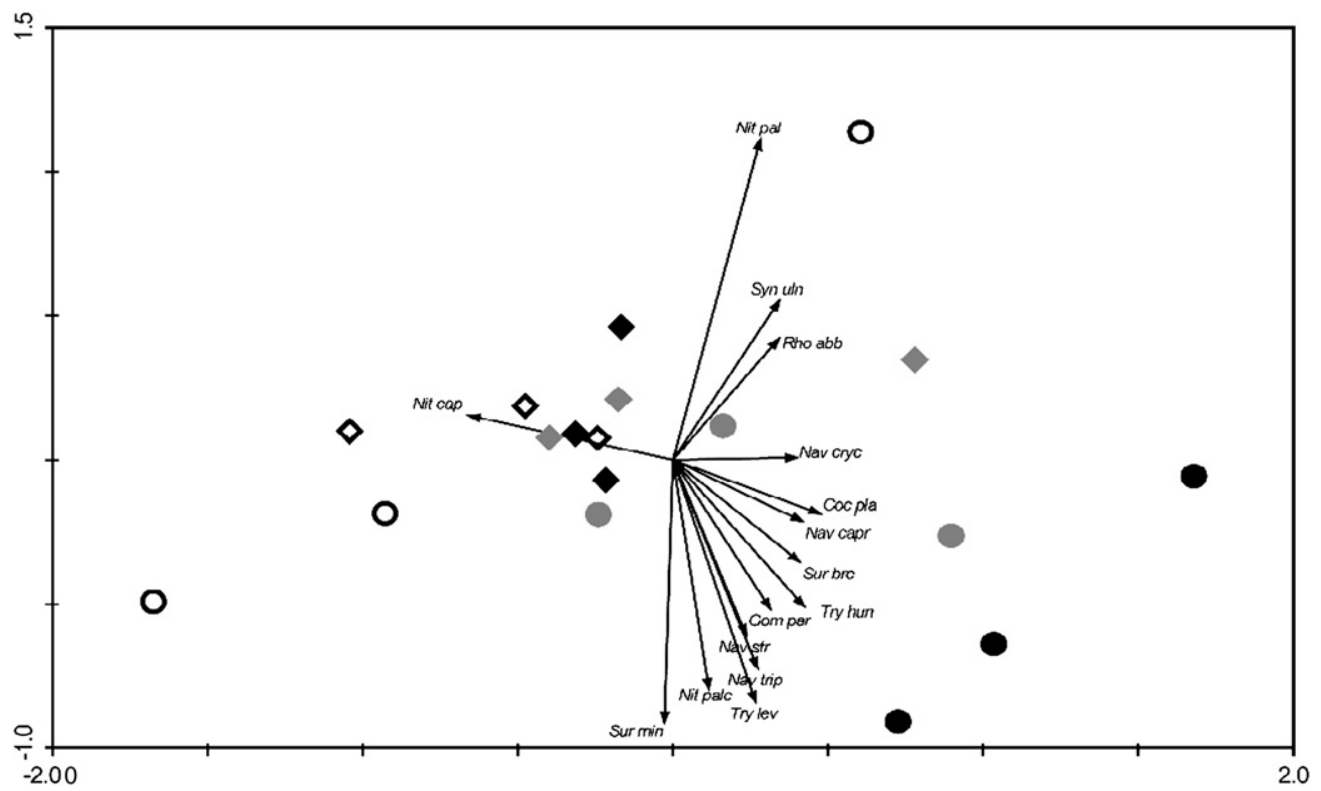

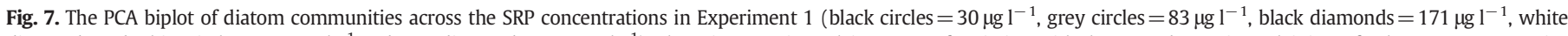

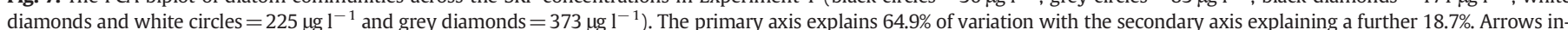

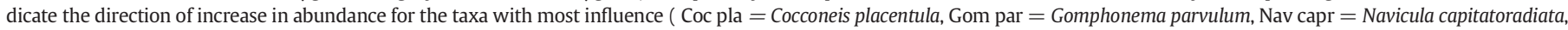

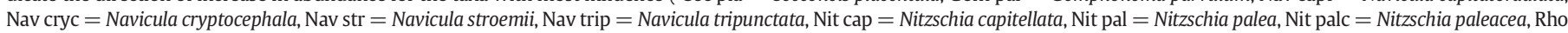

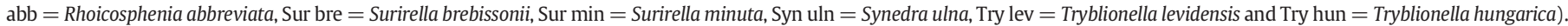


Table 2

Average nutrient concentrations produced during the nutrient addition experiment (Experiment 2).

\begin{tabular}{lllll}
\hline $\begin{array}{l}\text { Flume } \\
\text { number }\end{array}$ & Treatment & $\begin{array}{l}\text { Soluble reactive } \\
\text { phosphorus } \\
\mu \mathrm{g} \mathrm{I}^{-1}\end{array}$ & $\begin{array}{l}\text { Nitrate-N } \\
\mathrm{mg} \mathrm{l}^{-1}\end{array}$ & $\begin{array}{l}\text { Dissolved reactive } \\
\text { silicon } \\
\mathrm{mg} \mathrm{l}^{-1}\end{array}$ \\
\hline 1 & $\mathrm{~N}$ & 238 & 6.05 & 3.05 \\
2 & $\mathrm{P}, \mathrm{N}, \mathrm{Si}$ & 303 & 5.85 & 3.50 \\
3 & Control & 235 & 5.19 & 3.06 \\
4 & $\mathrm{P}, \mathrm{N}$ & 287 & 5.81 & 3.06 \\
5 & Control & 233 & 5.18 & 3.05 \\
6 & $\mathrm{P}$ & 302 & 5.18 & 3.05 \\
\hline
\end{tabular}

within the phytoplankton in the Thames at Wallingford at the time of this experiment. Greater differences in chlorophyll concentrations within the shading experiment (see below) also indicates that algal growth was taking place within the flumes and thus communities were not just a reflection of high rates of colonisation within a large river.

Thus, chlorophyll- $a$ concentrations responded more readily to the reduction in $\mathrm{P}$ concentrations than diatom community structure. Minor changes in algal community structure in response to a reduction in water P concentration has also been reported by Steinman et al. (1991), who attributed it to the relatively modest change in P concentration used in their study (from ca.7 to $3 \mu \mathrm{g} \mathrm{l}^{-1}$ ). However, in this study (as in a number of other studies e.g. Hill et al., 2009; Rosemond et al., 2000) a large range in P concentration was used, and it suggests that the diatom community is resistant to major changes in water phosphorus concentrations, at least over the short time scales investigated. Furthermore, it is likely that the species pool within the River Thames is dominated by taxa adapted to high nutrient concentrations.

\subsection{Effect of increasing nutrient concentrations on periphyton}

The nutrient concentrations observed in each flume during Experiment 2 are given in Table 2. Flumes receiving phosphorus additions had the SRP concentrations in the incoming river water increased from 235 to $\mathrm{ca} .300 \mathrm{~g} \mathrm{l}^{-1}$; equivalent to an increase of between 25 and $30 \%$. Nitrogen addition flumes had their average $\mathrm{NO}_{3}-\mathrm{N}$ incoming river water increased by $15 \%$, from 5.2 to $\mathrm{ca} .6 .0 \mathrm{mg} \mathrm{l}^{-1}$. The flume receiving additions of all three nutrients (Flume 2) also had its dissolved reactive silicon concentration increased by $15 \%$, from the average ambient river concentration of $3.05 \mathrm{mg} \mathrm{l}^{-1}$ to $3.5 \mathrm{mg} \mathrm{l}^{-1}$. A greater increase in ambient dissolved silicon concentration in this flume was not possible, due to rapid precipitation when the silicon stock solution entered the flume.

The quantities of chlorophyll- $a$ that had accrued on the tile substrates in each flume are shown in Fig. 8. There was no apparent difference between any of the nutrient-addition treatments and the controls. Furthermore, the highest average quantities of chlorophyll$a$ were actually observed in the control flumes receiving unmodified river water. This shows that periphyton at the study site are not limited, or co-limited by any of the three major plant nutrients; P, N or Si,

Table 3

The trophic diatom index, the percentage of diatoms that are motile and the diatom taxon diversity for each SRP concentration in experiment 1 . Values quoted as mean $\pm 1 \mathrm{SE}, \mathrm{n}=3$.

\begin{tabular}{lllll}
\hline $\begin{array}{l}\text { Soluble reactive } \\
\text { phosphorus } \\
\left(\mu \mathrm{g} \mathrm{l}^{-1}\right)\end{array}$ & Flume & $\begin{array}{l}\text { Trophic diatom } \\
\text { index }\end{array}$ & $\begin{array}{l}\text { Motile diatoms } \\
(\% \text { of frustules })\end{array}$ & $\begin{array}{l}\text { Shannon diversity } \\
\text { index }\end{array}$ \\
\hline 30 & 4 & $76.15 \pm 0.88$ & $71.46 \pm 0.24$ & $3.03 \pm 0.04$ \\
83 & 3 & $78.04 \pm 0.69$ & $82.02 \pm 2.52$ & $2.65 \pm 0.11$ \\
171 & 5 & $81.59 \pm 0.63$ & $80.04 \pm 2.22$ & $2.49 \pm 0.04$ \\
$225^{\mathrm{a}}$ & 1 & $77.45 \pm 1.77$ & $85.72 \pm 1.15$ & $2.27 \pm 0.07$ \\
$225^{\mathrm{a}}$ & 6 & $78.14 \pm 0.85$ & $80.49 \pm 1.76$ & $2.39 \pm 0.08$ \\
373 & 2 & $79.67 \pm 0.41$ & $83.00 \pm 2.03$ & $2.45 \pm 0.09$ \\
\hline
\end{tabular}

a River water concentration.

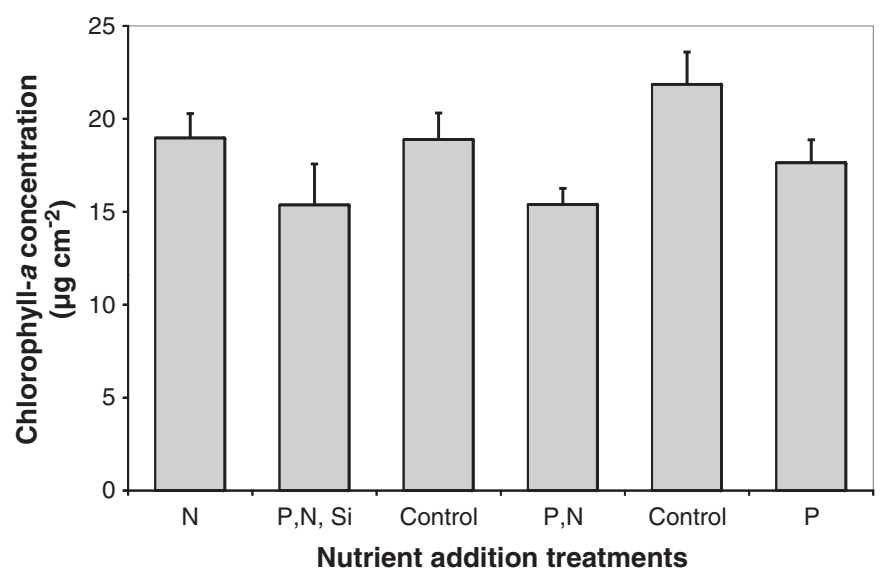

Fig. 8. Chlorophyll- $a$ concentrations on tile substrates at the end of the nutrient addition experiment (Experiment 2) (9 days), resulting from nutrient enrichment treatments. Data points are mean values \pm 1 standard error, based on analysis of 3 tiles from each flume.

during the experiment. From analysing the water quality monitoring data obtained from the River Thames at Swinford and at Wallingford, nitrate concentrations through 2010 were at their minimum concentration during late August (when the experiment took place). Therefore, periphyton at the study site will not be nitrogen-limited or colimited throughout the entire year. In contrast, phosphorus and silicon concentrations in the Thames at Swinford and Wallingford were approaching their annual maximums in August 2010, and were both at a minimum in April and May, and so there is a possibility that these nutrients may become limiting or co-limiting at other times of the year at the study site, and in particular during the spring period when concentrations are lowest and algal biomass (as measured by suspended chlorophyll- $a$ ) is usually at its highest.

In agreement with the chlorophyll data, there was also no impact of increasing nutrient concentrations on the composition of the diatom communities; in the RDA, concentrations of $\mathrm{P}, \mathrm{N}$ and $\mathrm{Si}$ were not significant (all canonical axes: $F=0.94, p=0.54$ ). Furthermore, TDI values were similar across treatments (river water $=77.07 \pm 0.10$; $\mathrm{N}$ addition $=77.81 \pm 0.94 ; \mathrm{P}, \mathrm{N}$ and $\mathrm{Si}$ addition $=78.44 \pm 0.97$ ) as were the percentage of diatoms that were motile (river water $=72.67 \pm 0.51 ; \mathrm{N}$ addition $=73.78 \pm 1.68 ; \mathrm{P}, \mathrm{N}$ and $\mathrm{Si}$ addition $=73.33 \pm 3.08)$.

\subsection{Effect of light intensity on periphyton}

The effect that the shading materials had on light intensities reaching the ceramic tile substrates are shown in Fig. 9. The tiles in the unshaded flumes (in direct sunlight for most of the day) received maximum light intensities of between 26000 to $58000 \mathrm{~lx}$ through the course of the experiment, with an average daily maximum of 44000 lx. The average light intensity during daylight hours was $15700 \mathrm{~lx}$. The flumes that had intermediate shading had maximum light intensities ranging from 16000 to 40000 , and an average daytime light intensity of $c a .10000$. This intermediate, partial shading reduced the maximum daytime light intensity in these flumes to $\mathrm{ca}$. 27000 and 10000 , equivalent to reducing direct sunlight by $\mathrm{ca} .35$ to $40 \%$. The fully shaded flumes had maximum light intensities of between 7000 and 19000 lx (Fig. 9), and an average daytime light intensity of $4500 \mathrm{~lx}$, which was equivalent to reducing direct sunlight by $\mathrm{ca}$. 70\%. These reductions in direct sunlight monitored within the flumes were closely comparable with those observed under partial and full tree canopy cover of 46 and $71 \%$ respectively, prior to the start of the experiment. Flume daily water temperatures (measured at hourly interval) ranged from 14 to $17^{\circ} \mathrm{C}$ throughout the study. The shading treatments had little effect on water temperature within the flumes, with all flumes having an average temperature of $15.8^{\circ} \mathrm{C}$. 


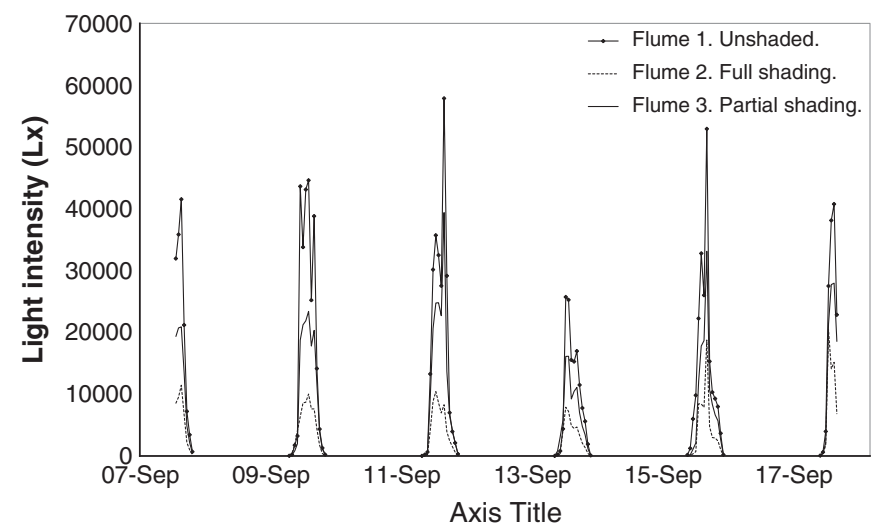

Fig. 9. Light intensity reaching tile substrates in Flumes 1 to 3 during flume shading experiment (Experiment 3), using submerged light sensors. Only data from alternate days (gathered following cleaning of the light sensor) are displayed. Unshaded flume in full sunlight, Intermediate shading equivalent to dappled tree-canopy shading. Full shading equivalent to full tree-canopy shading.

However, the unshaded flumes had their daytime maximum temperatures increased by $\mathrm{ca} .0 .4^{\circ} \mathrm{C}$.

The flumes in direct sunlight accrued significantly more periphyton than the shaded flumes $(F=12.16, p=0.003)$ (Fig. 10). Intermediate shading (equivalent to dappled tree shading) reduced the chlorophylla concentration by $30 \%$ in water velocities of $0.10 \mathrm{~m} \mathrm{~s}^{-1}$, and by $20 \%$ at $0.15 \mathrm{~m} \mathrm{~s}^{-1}$. The fully shaded flumes (equivalent to full riparian tree canopy cover) reduced the accrued periphyton biomass by 34 to $56 \%$, compared to flumes in full sunlight. The Autotrophic Index values for the unshaded flumes in the low and high flow velocity flumes (235 and 190 respectively) were much lower than the two fully shaded flumes (380 and 358), suggesting that reduced light levels were limiting the algal population. For all three shading treatments, there were no significant differences between high and low flow-velocities (unshaded; $t=0.03, p=0.978$ ), (partial shade; $t=-1.51, p=0.182$ ), (full shade; $t=0.86, p=0.416$ ), showing that this small difference in water velocity of $0.05 \mathrm{~m} \mathrm{~s}^{-1}$ had little effect on periphyton accrual rates. Further studies are needed to investigate the impact of flow velocity on biofilm accrual rate, using more representative ranges of velocities that are experienced by epiphytic and epilithic biofilms within river channels.

Light intensity also influenced diatom community composition (Fig. 11); the community growing in the full shade flumes were

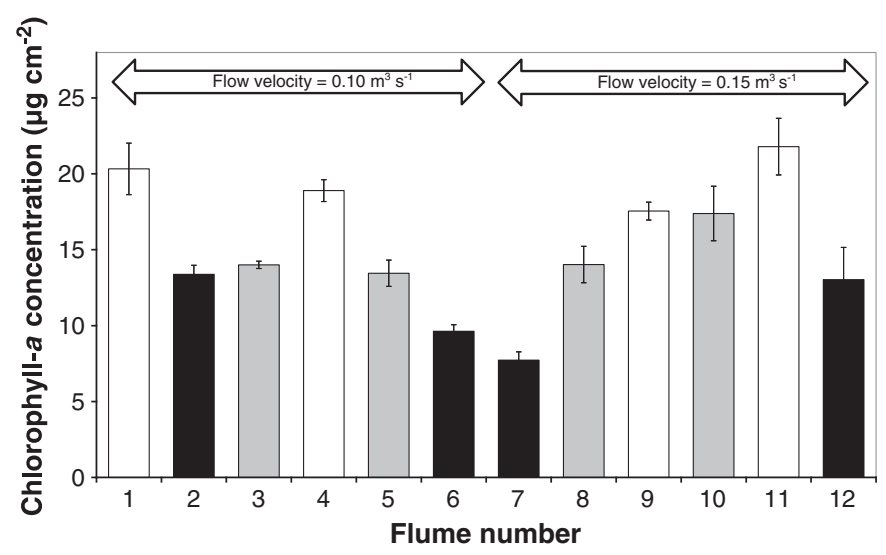

Fig. 10. Chlorophyll- $a$ concentrations on tile substrates after 10 days under different shading and flow velocity conditions (Experiment 3 ). Data points are mean values \pm 1 standard error, based on analysis of 3 tiles from each flume. Black bars $=$ full shading (equivalent to full tree canopy cover); Grey bars = intermediate shading (equivalent to dappled tree canopy shading); White bars $=$ no shading (full direct sunlight). Flumes 1 to $6=0.10 \mathrm{~m} \mathrm{~s}^{-1}$ water flow velocity. Flumes 7 to $12=0.15 \mathrm{~m} \mathrm{~s}^{-1}$ water flow velocity.

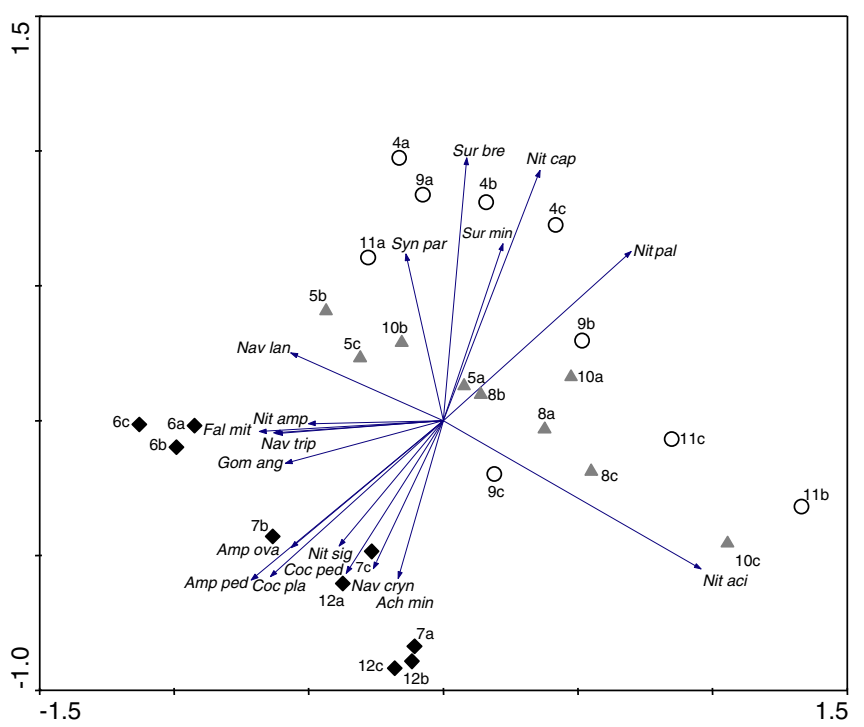

Fig. 11. The PCA biplot of diatom communities across the three shading levels in experiment 3 (Black circles = full shading; Grey circles = partial shading; White circles $=$ no shading). Scaling is focussed on inter-sample distances, and samples are labelled by flume number. The primary axis explains $33.4 \%$ of variation with the secondary axis explaining a further $26.6 \%$. Arrows indicate the direction of increase in abundance for the taxa with most influence (Ach min = Achnanthidium minutissimum, Amp ova = Amphora ovalis, Amp ped = Amphora pediculus, Coc ped = Cocconeis pediculus, Coc pla $=$ Cocconeis placentula, Fal mit $=$ Fallacia mitis, Gom ang = Gomphonema angustatum, Nav cryn = Navicula cryptotenella, Nav lan = Navicula lanceolata, Nav trip = Navicula tripunctata, Nit aci = Nitzschia acicularis, Nit amp = Nitzschia amphibian, Nit cap = Nitzschia capitellata, Nit pal = Nitzschia palea, Nit sig = Nitzschia sigmoidea, Sur bre = Surirella brebissonii, Sur min = Surirella minuta and Syn par = Synedra parasitica).

significantly different (RDA, $F=8.52, p=0.002,25 \%$ of variance in species data explained) from that found at higher light intensities. However, there was no difference in the mean TDI scores for the three treatments (no shade: $76.30 \%$, intermediate shade: $77.73 \%$, full shade: $77.38 \%$ ). Shaded flumes contained more diverse communities with a lower proportion of motile diatoms (Table 4). Shading was also found to reduce the proportion of motile diatoms in a recirculating flume study by Lange et al. (2011). As in the current study (Fig. 11), the motile diatom Nitzschia palea was less abundant in the shaded treatments, whereas the adnate diatoms Cocconeis placentula and Achnanthidium minutissimum occurred at higher abundances under reduced light (Lange et al., 2011). Motile diatoms are generally at an advantage within thick biofilms (e.g. biofilms growing in full sunlight), where their motility allows them to access light and nutrients more effectively than attached diatoms.

\subsection{Implications for future management of the River Thames catchment}

The water quality of the River Thames has greatly improved since the late 1990s, and this seems to be directly attributable to the STW improvements that have been introduced within the catchment. Phosphorus concentrations in the River Thames at Wallingford have been reduced ten-fold between 1997 and 2010, and nitrate concentrations have also been reduced by $26 \%$ during the same period.

Table 4

The taxon diversity (Shannon diversity index) and the percentage of diatoms that are motile in the three shading treatments in Experiment 3. Values are quoted as mean $\pm 1 \mathrm{SE}, \mathrm{n}=3$.

\begin{tabular}{lll}
\hline Treatment & $\begin{array}{l}\text { Shannon diversity } \\
\text { index }\end{array}$ & $\begin{array}{l}\text { Percentage of diatoms } \\
\text { that are motile }\end{array}$ \\
\hline Unshaded & $2.85 \pm 0.02$ & $83.71 \pm 0.54$ \\
Intermediate shading & $2.97 \pm 0.06$ & $81.48 \pm 1.70$ \\
Full shading & $3.24 \pm 0.10$ & $69.48 \pm 1.82$ \\
\hline
\end{tabular}


However, water quality monitoring within this study, in conjunction with earlier data sets (Neal et al., 2010a), have shown that phytoplankton biomass has greatly increased in the late 2000s, with the summer of 2009 having a maximum chlorophyll-a concentration of $328 \mu \mathrm{g} \mathrm{l} \mathrm{l}^{-1}$, a factor of ten higher than those seen in 1997 to 2002. Other studies have regularly observed similar maximum chlorophyll-a concentrations (of between 250 and $350 \mu \mathrm{gl}^{-1}$ ) in this part of the River Thames in the period 1980 to 1994 (Kinniburgh et al., 1997), prior to STW improvements. This is of great concern, as the reduction of phosphorus concentration is seen by UK policy makers and catchment managers as one of the main tools in delivering the good ecological status required under the WFD, and algal biomass is seen as the key symptom of eutrophication.

This study has shown that despite the dramatic reductions in nutrient enrichment, phosphorus and nitrate concentrations in the River Thames are still too high to limit or co-limit both phytoplankton and periphyton biomass. The use of the phosphorus stripping methodology within this study has shown that reducing the summer SRP concentration by a further $50 \mu \mathrm{g} \mathrm{l} \mathrm{l}^{-1}$ (to $171 \mu \mathrm{g} \mathrm{l}^{-1}$ ) would still have no effect on algal growth rates and algal community composition. It is also likely that such a P reduction would have no observable effect on the river's macrophyte and invertebrate assemblages, which also need to be improved to comply with the WFD. Some reduction in periphyton accrual rate would be observed at an SRP concentration of $83 \mu \mathrm{g} \mathrm{l} \mathrm{l}^{-1}$. These observations fit with the suggested average annual SRP targets to achieve good ecological status in the UK of $120 \mu \mathrm{g} \mathrm{l} \mathrm{l}^{-1}$ (UKTAG, 2008). Average summer SRP concentrations approaching $30 \mu \mathrm{g}^{-1}$ would need to be attained before a change in algal community structure would be observed, but even this $87 \%$ further reduction in SRP concentration would perhaps only reduce periphyton accrual rate by $25 \%$.

The River Thames catchment (like most catchments in lowland southern Britain) has high human population densities and intensive agricultural land use, and it is highly likely that attaining these stringent phosphorus concentration targets will be difficult and costly. However, nutrient reduction is not the only tool available to catchment managers to improve ecological status. This study has shown that providing riparian shading in the upper Thames perhaps offers an alternative tool to control nuisance algal growth and improve ecological status. Periphyton growth rate could be reduced by ca. $50 \%$ if the river channel was shaded from direct sunlight by riparian treecover. Similar observations have been made from studies of forested and open streams in Queensland, Australia (Mosisch et al., 2001) and USA (Greenwood and Rosemond, 2005; Jacobson et al., 2008). Modelling studies of the River Swale and River Ure in northern England have predicted 40 to $50 \%$ reductions in phytoplankton biomass could be achieved by providing riparian shading (Hutchins et al., 2010). However, the response of algal communities to light and nutrients is often inter-dependent (Hill et al., 2009; Rosemond et al., 2000), and manipulating both factors simultaneously within the River Thames could potentially lead to still further decreases in algal biomass, and this requires further investigation.

The large increases in chlorophyll- $a$ concentrations observed in the River Thames in 2009 and 2010 are clearly not related to increases in nutrient loading, as these particular years had the lowest phosphorus concentrations observed over the 13 year water-quality monitoring period. The flume experiments within this study have also shown that nutrients do not currently limit or co-limit periphyton growth, and therefore, other factors that can control algal biomass (such as river ecology/food-web interactions, light, water temperature and flow velocity) must be the cause of both the low algal biomass observed in 2006 and the major algal blooms in 2009 and 2010, rather than nutrient availability. Determining the causes of these huge annual fluctuations in algal biomass are key to understanding the process of eutrophication, and how we can effectively manage our rivers in the future.

\section{Acknowledgements}

This project was funded by the Natural Environment Research Council. The authors would like to thank FAI Farms Ltd. for allowing us to conduct the flume experiments at their Wytham farm site, and in particular, the support and assistance from Mike Gooding and David Crutchley. We would also like to thank the University of Oxford and the John Krebs Field Station for providing their laboratory facilities, especially Phil Smith. We would especially like to thank Professor Colin Neal for supplying his long-term water quality data for the River Thames.

\section{References}

Ameziane T, Garabetian F, Dalger D, Sauvage S, Dauta A, Capblancq J. Epilithic biomass in a large gravel-bed river (the Garonne, France): a manifestation of eutrophication? River Res Appl 2002;18(4):343-54.

APHA. Standard methods for the examination of water and wastewater. Washington D.C., USA: American Public Health Association; 1995.

Bothwell ML. Phosphorus limitation of lotic periphyton growth-rates-an intersite comparison using continuous-flow troughs (Thompson River system, BritishColumbia). Limnol Oceanogr 1985;30(3):527-42.

Bowes MJ, Smith JT, Hilton J, Sturt MM, Armitage PD. Periphyton biomass response to changing phosphorus concentrations in a nutrient-impacted river: a new methodology for phosphorus target setting. Can J Fish Aquat Sci 2007;64(2):227-38.

Bowes MJ, Smith JT, Jarvie HP, Neal C, Barden R. Changes in point and diffuse source phosphorus inputs to the River Frome (Dorset, UK) from 1966 to 2006. Sci Total Environ 2009;407(6):1954-66.

Bowes MJ, Neal C, Jarvie HP, Smith JT, Davies HN. Predicting phosphorus concentrations in British rivers resulting from the introduction of improved phosphorus removal from sewage effluent. Sci Total Environ 2010a;408(19):4239-50.

Bowes MJ, Lehmann K, Jarvie HP, Singer AC. Investigating periphyton response to changing phosphorus concentrations in UK rivers using within-river flumes. British Hydrological Society International Conference, University of Newcastle-uponTyne; 2010b. p. 6

Bowes MJ, Smith JT, Neal C, Leach DV, Scarlett PM, Wickham HD, Harman SA, Armstrong LK, Davy-Bowker J, Haft M, Davies CE. Changes in water quality of the River Frome (UK) from 1965 to 2009: Is phosphorus mitigation finally working? Sci Total Environ 2011;409(18):3418-30.

Chambers PA, Culp JM, Glozier NE, Cash KJ, Wrona FJ, Noton L. Northern Rivers Ecosystem Initiative: nutrients and dissolved oxygen-issues and impacts. Environ Monit Assess 2006;113(1-3):117-41.

Environment_Agency. River Basin Management Plan. Thames River Basin District. Bristol, UK: Environment Agency; 2009. p. 89.

Evans SG, Spillett PB, Colphoun K. South-East housing development-the quest for sustainability: water and sewerage needs. J Chart Inst Water Environ Manage 2003;17(4):257-61.

Foy RH. Variation in the reactive phosphorus concentrations in rivers of northwest Europe with respect to their potential to cause eutrophication. Soil Use Manage 2007;23: 195-204.

Fuller RM, Smith GM, Sanderson JM, Hill RA, Thomson AG. The UK Land Cover Map 2000: construction of a parcel-based vector map from satellite images. Cartogr J 2002;39(1):15-25.

Greenwood JL, Rosemond AD. Periphyton response to long-term nutrient enrichment in a shaded headwater stream. Can J Fish Aquat Sci 2005;62(9):2033-45.

Hill WR, Fanta SE. Phosphorus and light colimit periphyton growth at subsaturating irradiances. Freshw Biol 2008;53:215-25.

Hill WR, Fanta SE, Roberts BJ. Quantifying phosphorus and light effects in stream algae. Limnol Oceanogr 2009;54(1):368-80.

Hilton J, O'Hare M, Bowes MJ, Jones JI. How green is my river? A new paradigm of eutrophication in rivers. Sci Total Environ 2006;365(1-3):66-83.

Horner RR, Welch EB, Seeley MR, Jacoby JM. Responses of periphyton to changes in current velocity, suspended sediment and phosphorus concentration. Freshw Biol 1990;24(2):215-32.

House WA. Geochemical cycling of phosphorus in rivers. Appl Geochem 2003;18(5): 739-48.

House WA, Warwick MS. Intensive measurements of nutrient dynamics in the River Swale. Sci Total Environ 1998;210(1-6):111-37.

Hutchins MG, Johnson AC, Deflandre-Vlandas A, Comber S, Posen P, Boorman D. Which offers more scope to suppress river phytoplankton blooms: reducing nutrient pollution or riparian shading? Sci Total Environ 2010;408(21):5065-77.

Jacobson LM, David MB, Mitchell CA. Algal growth response in two Illinois rivers receiving sewage effluent. J Freshw Ecol 2008;23(2):179-87.

Jarvie HP, Withers PJA, Neal C. Review of robust measurement of phosphorus in river water: sampling, storage, fractionation and sensitivity. Hydrol Earth Syst Sci 2002a;6(1):113-31.

Jarvie HP, Neal C, Williams RJ, Neal M, Wickham HD, Hill LK, et al. Phosphorus sources, speciation and dynamics in the lowland eutrophic River Kennet, UK. Sci Total Environ 2002b;282:175-203.

Johnson AC, Acreman MC, Dunbar MJ, Feist SW, Giacomello AM, Gozlan RE, et al. The British river of the future: how climate change and human activity might affect two contrasting river ecosystems in England. Sci Total Environ 2009;407(17):4787-98. 
Kelly MG, Wilson S. Effect of phosphorus stripping on water chemistry and diatom ecology in an eastern lowland river. Water Res 2004;38(6):1559-67.

Kelly MG, Adams C, Graves AC, Jamieson J, Krokowoski J, Lycett EB, et al. The trophic diatom index: a user's manual. Revised editionEnvironment Agency; 2001. p. 146.

Kelly MG, Bennion H, Cox EJ, Goldsmith B, Jamieson J, Juggins S, et al. Common freshwater diatoms of Britain and Ireland: an interactive key. Bristol: Environment Agency; 2005. pp.

Kelly MG, Haigh A, Colette J, Zgrundo A. Effect of environmental improvements on the diatoms of the River Axe, southern England. Fottea 2009;9(2):343-9.

Kinniburgh JH, Barnett M. Orthophosphate concentrations in the River Thames: reductions in the past decade. Water Environ J 2010;24(2):107-15.

Kinniburgh JH, Tinsley MR, Bennett J. Orthophosphate concentrations in the River Thames. Water Environ J 1997;11(3):178-85.

Krammer K, Lange-Bertalot H. Bacillariophyceae, 4, Teil: Achnanthaceae kritische Ergänzungen zu Achnanthes s.l., Navicula s. str., Gomphonema, 2. Heidelberg: Spektrum Akademischer Verlag; 2004a. 468 pp.

Krammer K, Lange-Bertalot H. Bacillariophyceae, 3, Teil: Centrales, Fragilariaceae, Euntotiaceae, 2. Heidelberg: Spektrum Akademischer Verlag; 2004b. 598 pp.

Krammer K, Lange-Bertalot H. Bacillariophyceae, 1, Teil: Naviculaceae, 2. Heidelberg: Spektrum Akademischer Verlag; 2007a. 876 pp.

Krammer K, Lange-Bertalot H. Bacillariophyceae, 2, Teil: Bacillariaceae, Epithemiaceae, Surirellaceae, 2. Heidelberg: Spektrum Akademischer Verlag; 2007b. 610 pp.

Lange K, Liess A, Piggott JJ, Townsend CR, Matthaei CD. Light, nutrients and grazing interact to determine stream diatom community composition and functional group structure. Freshw Biol 2011;56:264-78.

Leps J, Smilauer P. Multivariate analysis of ecological data using CANOCO. Faculty of Biological Sciences. University of South Bohemia: Ceske Budejovice; 2002. p. 175.

Marker AFH, Nusch EA, Rai H, Riemann B. The measurement of photosynthetic pigments in freshwaters and standardisation of methods: conclusions and recommendations. Arch Hydrobiol Beih 1980;14:91-106.

Marsh TJ, Hannaford J. UK Hydrometric Register. Hydrological data UK series. Centre for Ecology and Hydrology; 2008. p. 210.

Matlock MD, Storm DE, Smolen MD, Matlock ME. Determining the lotic ecosystem nutrient and trophic status of three streams in eastern Oklahoma over two seasons. Aquat Ecosyst Health Manage 1999;2:115-27.

Merrett S. The Thames catchment: a river basin at the tipping point. Water Policy 2007;9(4):393-404.

Mosisch TD, Bunn SE, Davies PM. The relative importance of shading and nutrients on algal production in subtropical streams. Freshw Biol 2001;46(9):1269-78.
Mullin JB, Riley JP. The colourometric determination of silicate with special reference to sea and natural waters. Anal Chim Acta 1955;12:31-6.

Murphy J, Riley JP. A modified single solution method for the determination of phosphorus in natural waters. Analytica chemica acta 1962;12:31-6.

Neal C, Jarvie HP. Agriculture, community, river eutrophication and the water framework directive. Hydrol Process 2005;19(9):1895-901.

Neal C, Neal M, Wickham H. Phosphate measurement in natural waters: two examples of analytical problems associated with silica interference using phosphomolybdic acid methodologies. Sci Total Environ 2000;251:511-22.

Neal C, Hilton J, Wade AJ, Neal M, Wickham H. Chlorophyll-a in the rivers of eastern England. Sci Total Environ 2006;365(1-3):84-104

Neal C, Jarvie HP, Williams R, Love A, Neal M, Wickham H, et al. Declines in phosphorus concentration in the upper River Thames (UK): links to sewage effluent cleanup and extended end-member mixing analysis. Sci Total Environ 2010a;408(6): 1315-30.

Neal C, Martin E, Neal M, Hallett J, Wickham HD, Harman SA, et al. Sewage effluent clean-up reduces phosphorus but not phytoplankton in lowland chalk stream (River Kennet, UK) impacted by water mixing from adjacent canal. Sci Total Environ 2010b;408(22):5306-16.

Popova YA, Keyworth VG, Haggard BE, Storm DE, Lynch RA, Payton ME. Stream nutrient limitation and sediment interactions in the Eucha-Spavinaw Basin. J Soil Water Conserv 2006;61(2):105-15.

Reynolds CS, Davies PS. Sources and bioavailability of phosphorus fractions in freshwaters: a British perspective. Biol Rev 2001;76(1):27-64.

Rosemond AD, Mulholland PJ, Brawley SH. Seasonally shifting limitation of stream periphyton: response of algal populations and assemblage biomass and productivity to variation in light, nutrients and herbivores. Can J Fish Aquat Sci 2000;27:66-75.

Steinman AD, Mulholland PJ, Kirschtel DB. Interactive effects of nutrient reduction and herbivory on biomass, taxonomic structure, and $\mathrm{P}$ uptake in lotic periphyton communities. Can J Fish Aquat Sci 1991;48:1951-9.

Suschika J, Machnicka A, Poplawski S. Phosphates recovery from iron phosphates sludge. Environ Technol 2001;22(11):1295-301.

UKTAG. UK Environmental Standards and Conditions (Phase 1). Technical Advisory Group on the Water Framework Directive; 2008. p. 72.

Welch EB, Horner RR, Patmont CR. Prediction of nuisance periphytic biomass: a management approach. Water Res 1989;23(4):401-5. 